University of Nebraska - Lincoln

DigitalCommons@University of Nebraska - Lincoln

Management Department Faculty Publications

Management Department

6-2007

\title{
Shared leadership theory
}

Craig L. Pearce

University of Nebraska - Lincoln, cpearce2@unl.edu

Jay A. Conger

Claremont McKenna College

Edwin A. Locke

University of Maryland

Follow this and additional works at: https://digitalcommons.unl.edu/managementfacpub

Part of the Management Sciences and Quantitative Methods Commons

Pearce, Craig L.; Conger, Jay A.; and Locke, Edwin A., "Shared leadership theory" (2007). Management Department Faculty Publications. 74.

https://digitalcommons.unl.edu/managementfacpub/74

This Article is brought to you for free and open access by the Management Department at DigitalCommons@University of Nebraska - Lincoln. It has been accepted for inclusion in Management Department Faculty Publications by an authorized administrator of DigitalCommons@University of Nebraska - Lincoln. 
Published in The Leadership Quarterly 18:3 (June 2007), pp. 281-288; doi:10.1016/j.leaqua.2007.03.009

Copyright () 2007 Elsevier Inc. Used by permission.

Published online April 25, 2007.

\title{
Shared leadership theory
}

\author{
Craig L. Pearce, ${ }^{1}$ Jay A. Conger, ${ }^{2}$ and Edwin A. Locke ${ }^{3}$ \\ 1. Claremont Graduate University, 1021 N. Dartmouth Avenue, Claremont, CA 91711, USA \\ 2. Claremont McKenna College, 850 Columbia Ave., Claremont, CA 91711, USA \\ 3. University of Maryland (emeritus), 32122 Canyon Ridge Drive, West Lake Village, CA 91316, USA
}

Corresponding author - C. L. Pearce

\begin{abstract}
Edwin Locke contributed a chapter to the critique section of Craig Pearce and Jay Conger's (2003a) edited book, Shared Leadership: Reframing the Hows and Whys of Leadership, published by Sage. In this letter exchange, they continue their dialogue on this important topic. They focus in particular on clarifying what each means by "shared leadership" and on what shared leadership can and should look like at the top of organizations.
\end{abstract}

Keywords: shared leadership, integrated leadership, top-down leadership, lateral influence

\section{Letter 1}

Edwin A. Locke

Dean's Professor of Leadership and Motivation (Emeritus)

University of Maryland

32122 Canyon Ridge Drive

West Lake Village, CA 91316

\section{Dear Ed:}

We found the ideas in your critique chapter (Locke, 2003a) in our book, Shared Leadership (Pearce \& Conger, 2003a), challenging and provocative. As you know, the purpose of the book was to put a stake in the ground, so to speak, on shared leadership theory: We wanted to advance inquiry into leadership processes outside the typical top-down paradigm of leadership. Thus, in this letter, we summarize some of the main points you made in your critique chapter and offer alternative perspectives to further clarify the research agenda for shared leadership theory.

The four leadership models you described present a particularly useful foil for describing the mechanisms through which leadership and influence may be exercised and "travel" within a group of people: Top-down; bottom-up; lateral (what you termed shared leadership); and integrated - a combination of top-down, bottom-up, and lateral leadership. As you suggested, most research and practitioner thinking on leadership focuses on the top-down model. We believe the top-down model of leadership is but a seductive siren song relative to the real-life enactment 
of leadership in organizations. Clearly, leadership is a far more complex process, involving a dynamic give-and-take that shared leadership theory attempts to describe and address.

We agree, in large part, with your final conclusions - that what you term the integrated model is the appropriate lens through which to view leadership. In fact, your integrated model is fairly consistent with the definition of shared leadership we offered in our introductory chapter: Shared leadership is "a dynamic, interactive influence process among individuals in groups for which the objective is to lead one another to the achievement of group or organizational goals or both. This influence process often involves peer, or lateral, influence and at other times involves upward or downward hierarchical influence" (Pearce \& Conger, 2003b, p. 1). Nonetheless, while much of your discussion is consistent with ours, a few areas exist where we have divergent opinions - particularly concerning the section of your chapter where you enumerate the tasks of the top leader and point out which of these tasks can be properly shared with others and which cannot. We wish to explore several of these issues with you further.

For one, we feel that your model of leadership best describes the senior level leadership of vertically-integrated bureaucratic organizations. In reality, these types of leadership scenarios are increasingly rare, even in the world of business. More organizations today are a set of coalitions, networks, and strategic alliances. As Dunphy (2000) points out, this newer generation of organizations do not have a centralized, unitary command structure rather they are often a loose alliance built around a common interest. Leadership is often shared across the various partners or members making it difficult for a single individual of one entity to truly lead the alliance or network. For example, Microsoft and Intel have a deep, historic partnership and Bill Gates of Microsoft does not alone determine the strategies and tactics of that partnership. What are your thoughts on this perspective?

You also clearly state that one of the tasks of leadership - the creation of the vision for the organization - is the sole prerogative of the top leader. Again, we feel that the new generation of organizations built around alliances and joint ventures require strategic visions shaped by multiple parties - in these cases, the senior leaders of the partnership. In such cases, there is rarely if ever a single senior leader shaping the alliance vision. It is more often the product of shared leadership across a set of senior executives representing the different enterprise partners to the venture.

Even in the case of entrepreneurial leaders, the strategic vision may be profoundly shaped by an executive who is not the CEO founder. One illustrative example would be the fast food company McDonalds. Harry Sonneborn, the chief financial officer to company founder Ray Kroc, envisioned the real estate component of the company's strategic vision which in turn enabled McDonald's to become a viable competitor in fast food and ensured its profitability. Sonneborn formulated a novel way for McDonalds to be profitable without conflicting with Kroc's concept of fairness to suppliers and franchisees. Sonneborn's vision was built around a separate real estate company which located and leased restaurant sites from landowners willing to build McDonald's stores. This company then entered into 20year leases with the property owners and in turn subleased the stores to the franchisees, with a markup charged for the real estate services McDonalds provided to the latter. This practice provided a stream of long term predictable profits to McDonalds which in turn allowed Kroc to successfully implement the other elements of his own vision for the company (Love, 1986). In this case, the actual strategic vision for McDonalds was the product of at least two individuals excluding the McDonalds brothers who laid much of the earlier groundwork for the company's strategic vision. Similarly, research by Nadler (1998) found in publicly traded companies that the executive team is vital to the formulation of the strategic vision. They possess a wide range of creative and viable perspectives given their breadth of experience and seasoned judgment in the business. In many different ways, members of the executive team are direct contributors to the formulation and articulation of the strategic vision.

Furthermore, on the dimension of vision, emerging research suggests that vision created collectively through shared leadership can have a powerful influence on many team dynamics as well as team performance (e.g., Pearce \& Ensley, 2004). Moreover, research has found that top management team member involvement in creating the organizational vision can be more important than the actual vision itself in explaining firm performance (Ensley \& Pearce, 2001). Thus, it appears that if people are properly motivated, and have the necessary knowledge skills and abilities, a vision shaped collectively by the team is not only possible but also potentially more powerful than one imparted from above. We wonder what your thoughts might be on these issues related to vision formulation.

Another dimension where our views diverge is in the area of motivating people. We agree that while a degree of responsibility for motivation rests with the top leader of any group or organization, this does not preclude the possibility of more motivation being created and engendered by managers and teammates who do not occupy formal roles of authority within a team. To wit, consider the case of knowledge workers (e.g., Hooker \& Csikszentmihalyi, 2003), whose considerable expertise may form a highly desirable basis of power and leadership - which is consistent 
with Kerr \& Jermier's (1978) articulation of substitutes for leadership - between peers in an effort to develop breakthrough products, processes, or services. On the other hand, consider the case of virtual teams - those that work from geographically dispersed locations. Often the formal leader will not be available to these individuals as readily as other team members. In this scenario, the top leader may have the ultimate responsibility for motivation, but the reality may be that the day-to-day, minute-to-minute source of motivation is, in fact, more dispersed and shared by team members, as suggested in research by Pearce, Yoo, \& Alavi (2004). How do these contexts sit with your emphasis on the top leader as the primary source of motivation?

An additional area where we have a difference in point of view is in the area of promoting change, which you classify as a primary task of the top leader. We believe that leading change is not about an individual leader, but rather that it is such an immensely complex process where leadership occurs at multiple levels. Top-down initiatives for change appear to have greater success when they are well orchestrated by leaders at local or more junior levels and are linked in a sensitive and coherent manner to bottom-up or lower level concerns ( Kotter and Cohen, 2002; Pettigrew et al., 1992). In radical change efforts, for instance, research suggests that middle managers play an absolutely critical role in providing entrepreneurial leadership and in offering viable solutions for the change effort (Huy, 2001). Moreover, recent research by Pearce \& Sims (2002) suggests that shared leadership between peers accounts for more variance in team self-ratings, manager ratings, and customer ratings of change management team effectiveness than the leadership of formally designated team leaders. How might this fit in with your model of leadership?

Finally, while we clearly agree that there is a role for vertical/hierarchical leadership, it also seems that over-reliance on a single individual at the top opens any organization to a certain degree of risk (Conger \& Kanungo, 1998). This is especially true for senior leaders who may create dependence among their staff to the point that staffs themselves do not develop similar leadership capabilities. Their centralized control may also drive out capable junior leaders who desire greater autonomy and authority. Finally, they may procrastinate on succession plans such that few adequate successors are in the wings. What then happens if the top leader departs the group or organization? Does this not create a potentially risky void for a group or organization that relies heavily on a single leader at the top (McCauley, Moxley, \& Van Velsor, 1998)? Does not a more shared leadership process offer a more robust overall system that can cope with the shocks and disturbances of an uncertain world? What do you think?

While there are, clearly, other nuances and subtleties of shared leadership theory that require further exploration and explication, we are most interested in your views on the issues listed above. Also, in fairness to you, we note that you state "none of this [what you state should not be shared] precludes the CEO from getting ideas from below" (Locke, 2003a, p. 279). While we resoundingly agree with your statement, vis-à-vis your overall commentary, we simply view an expanded role for "followers" in the leadership process. As always, we look forward to hearing from you.

Best Regards,

Craig L. Pearce

Jay A. Conger

\section{Letter 2}

Craig Pearce

Associate Professor

Peter F. Drucker and Masatoshi Ito Graduate School of Management

Claremont Graduate University

1021 N. Dartmouth Avenue

Claremont, CA 91711

Jay Conger

Henry R. Kravis Research Chair in Leadership Studies

Claremont McKenna College

850 Columbia Ave.

Claremont, CA 91711 
Dear Craig and Jay:

This is in response to your comments on my chapter on shared leadership. I believe that the differences you point out between my position and yours are due mainly to three things: definition switching; equivocation; and attributing views to me which I do not hold due to the failure to read my chapter carefully.

In Chapter Three of Shared Leadership (Cox, Pearce, \& Perry, 2003, p. 48) you define shared leadership as "lateral influence among peers rather than vertical downward influence by an appointed leader." This is the definition I quoted in my chapter (Locke, 2003a). However, in your letter you quote a different definition from a different chapter of the book (Pearce \& Conger, 2003b, p.1), "shared leadership...often involves peer or, lateral, influence and at other times involves upward or downward hierarchical influence."

These two definitions obviously contradict one another. The first definition above has the advantage of differentiating shared leadership from other types of leadership, whereas the second one does not. My definition of leadership, "the process of inducing others to take action toward a common goal" (Locke, 2003a, p. 271), does not specify any particular direction but implies that it could be in any direction and this is also shown in my integrated model. My definition does not preclude their being different directions of influence (lateral, downward, upward, or even diagonal). The point is to be clear about what you mean. Shared leadership, by which you seem in one definition to mean lateral, is not something I oppose in principle; rather I argue that it is not adequate for a full or integrated leadership model and that it is impractical if done at the top of the organization, because someone has to have the final say.

After agreeing in general with my integrated model in your third paragraph, in your fourth paragraph you claim that my model is actually too limited because it does not apply in today's business world, in that modern organizations consist of a set of coalitions, networks, and strategic alliances.

But there is a serious equivocation here. Who is it that engages in these coalitions, networks and alliances? You give one example: cooperation between Microsoft and Intel. You fail to mention that Microsoft and Intel are two separate companies, each run by its own CEO, each having its own employees, stockholders, and boards of directors. Gates never ran Intel and Grove and his successor never ran Microsoft. In each case the CEO (perhaps with the help of the top management team) decides whether and on what terms his company will work in partnership with other companies. When conditions change, the CEO may shift alliances and make agreements with the CEOs of different companies. Such shifting alliances do not wipe out the existence of any of the companies nor remove its responsibility for determining its own competitive strategy. This only occurs if one company is sold to another.

Your argument then shifts to what goes on within a given company using McDonalds as an example. You argue that Harry Sonneborn, the CFO, was critical to the success of McDonalds. Let us assume that you are correct on this. You then go on to say that executive teams have been found in other research to be vital to the formulation of strategic visions and that such teams may develop a better vision than "one imparted from above." I agree, they might, but how does any of this contradict anything that I said in my chapter? For example, I ask (Locke, 2003a, pp. 280-281): "Should CEOs listen to others' opinions regarding any of the above [leadership] issues, including those that are their sole prerogative? My answer is a strong yes, even with respect to formulating a vision, choosing core values, and choosing the top management team. CEOs should listen to anybody - inside or outside the company - who has a potentially good idea about any subject relevant to the company's mission." My reason for supporting a hierarchical, rather than say a horizontal, leadership model was precisely the fact that in the end the CEO has to make the final choice. The reason for this is to prevent organizational chaos and anarchy. Organizations need a clear sense of purpose and mission; groups do not always agree and in the end somebody has to have the authority to stand up and say, "I have heard and studied all your opinions; now this is what I have decided to do."

The only way our opinions could diverge on this is if you deny that the CEO's input is critical and that in the end the CEO has to make the final decision. Maybe you would want to argue that all top-level decisions should be made by group consensus. But I think this would be a poor idea. Over and above the possibility of anarchy due to the group not reaching consensus and each executive going his own way, you might have paralysis with no decision being made by anyone. You might also end up with a vision or strategy that is so watered down, in order to please everyone, that it is meaningless.

My own research on great wealth creators (Locke, 2000) found that great companies, are, no matter what the input of others, in the end the creations of a single mind, the product of a single coherent vision. The vision is supported by other important CEO traits such as ability, active thinking, confidence, drive, egoistic passion, virtue and love of ability in others. 
You go on to say, "We agree that while a degree of responsibility for motivation rests with the top leader of any group or organization, this does not preclude the possibility of more motivation being created and engendered by managers and teammates who do not occupy formal roles of authority within a team." You are referring here to team members. Here is what I said in my chapter in the section entitled "What Can Be, At Least in Part, Shared" (Locke, 2003a, p. 279), "Motivation must occur at all levels, with the CEO focusing mainly on motivation in the top management team....Goal setting, empowerment, confidence building, and recognition should be practiced throughout the organization. The CEO may set the goals at the top but may properly delegate the rest." Again, where is the disagreement?

You also claim to disagree on the issue of promoting change, arguing that top down initiative may have more chance of success if they are orchestrated by those at lower levels. Here is what I said (Locke, 2003a, p. 279), "Organizational change can occur at all levels of the organization. The CEO will need to lead it...if it is a company wide-change program" as Jack Welch did at GE with the Six Sigma program. I go on to recommend empowerment (delegation) as long as the followers act in consonance with the vision, core values, and goals of the organization. How does this contradict your position? Was it that I did not mention peer influence? This may well be important, though your one study does not prove the case. But peer influence will not do any good unless the peers are in sync with the organizational change program. Someone has to make clear what needs changing and why.

Finally, you argue that "over-reliance on a single individual at the top opens any organization to a certain degree of risk...senior leaders may create dependence...centralized control may...drive out capable junior leaders" and leave few able subordinates as successors. Here is what I wrote (Locke, 2003a, p. 281), "To fail to [listen to others] carries the implication that the CEO is omniscient, a very irrational premise. In fact, CEOs should go way beyond just listening.... They should... proactively seek out knowledge from other people. If CEOs choose very capable people to work for them, then inevitably they are going to know things that the CEO does not know. To hire smart people and then fail to listen to their ideas is a contradiction and also self-destructive." How does this quote in any way imply overdependence? In fact, it asserts just the opposite: hire smart people and use their knowledge in every way possible.

In conclusion, if there is something about which we really disagree, please let me know. If you are trying to protest against the top-down-only model, you do not need to convince me. I was never for it in the first place. Nor am I for lateral leadership by itself, although it may be useful in some cases. Please observe that my integrated model advocates influence in all different directions while retaining the practical necessity of a hierarchy and of having a top leader who makes the final decisions on key issues. If you wish to defend a different model, let us hear it.

Sincerely,

Edwin Locke

\section{Letter 3}

Edwin A. Locke

Dean's Professor of Leadership and Motivation (Emeritus)

University of Maryland

32122 Canyon Ridge Drive

West Lake Village, CA 91316

\section{Dear Ed:}

Thank you for your challenging response to our letter. You articulate well the small margin of difference between our views. In response to your first two related critiques of our letter - that we have engaged in definition switching and equivocation - we disagree. For the sake of clarity, the exact quote from Cox et al. (2003, p. 48) defines shared leadership as including "lateral influence among peers rather than simply relying on [italics added for emphasis] vertical, downward influence by an appointed leader." This definition is consistent with the Pearce \& Conger (2003b) definition, as the three words in italics make a significant difference in the meaning of the quote.

Nevertheless, you raise an important point: Theory must rely on precise definitions of phenomena and definitional clarity has long been an issue in leadership theory. We believe the crux of this issue is the challenge of integrating 
the view of leadership as a role performed by an individual with the view of leadership as a social process. Shared leadership theory is an explicit attempt at integrating these two important perspectives. Nonetheless, given the infancy of shared leadership theory, it is not surprising that this is an issue that requires attention - shared leadership is, after all, still a relatively "primitive term." Having said that, additional empirical work is now needed to inform theory development. This issue was specifically addressed in Pearce's (1997) initial articulation of shared leadership theory where he identified the possibility of either including or excluding the behavior of the higher level leader in the measurement of shared leadership - depending on the context. On the one hand, drawing a distinction between the two types of leadership affords the ability to examine each source of influence independently. On the other hand, folding leadership from above into the measurement of shared leadership provides a more parsimonious model, as suggested by Avolio, Sivasubramaniam, Murry, Jung, \& Garger (2003). It also reflects the reality of leadership in many workplaces. What is needed at this stage in the field's development is more empirical research to explore how best to operationalize and test shared leadership (see Conger and Pearce, 2003 for a description of alternative methods). That said, it appears that we agree that a shared leadership model - what you term the integrated model - is superior to other less dynamic or narrow models of influence processes in organizations.

On your third point that we have attributed views to you that you do not hold due to the failure to read carefully your chapter (Locke, 2003a), we disagree - we read your chapter with great care. Our interpretations were a result of the way certain issues were framed in your chapter. This led us to a different understanding of some of your points than what you so ably elucidated in your letter. For example, there is a section of your chapter entitled "what should not be shared," which includes such things as vision, selection, and so on. Because these issues were framed so definitively, it appeared to us that you viewed the formal leader of the group as much more in the role of commander than we do. Your letter more precisely clarified your actual views for us.

While we believe that the top designated leader of any organization or group has the final say, we argue that the heavy use of formal position power at the top is not the ideal source of leadership in most organizational circumstances, especially in the Western world. We believe that relying on position power for making decisions may actually backfire. Why? Because top-down decision making does not necessarily ensure a shared sense of purpose or better goal alignment: It does not cause alternative perspectives from below to suddenly disappear. On the contrary, topdown decision making seems most likely to result in compliance, rather than consensus. In the end, heavy reliance on position power might ultimately result in active efforts to undermine the position power of the top leader.

Nonetheless, as you state, relying solely on group consensus as the means for making decisions at the top of organizations - or any level for that matter - would be a misguided strategy. Having said that, we would argue that consensus is a highly preferable approach when the appropriate conditions are in place (e.g. knowledgeable and empowered individuals who are in possession of the necessary resources and authority). We therefore see team decision making with consensus as an important default mode only to be supplanted when organizational circumstances necessitate it. Why? Because consensus promotes voluntary and deeper commitment and often greater understanding of a challenge or goal, which your own research has clearly demonstrated are keys to long term goal attainment (Locke \& Latham, 1990). By this we do not mean to imply that a vision shaped through consensus is necessarily better than one derived through a unilateral declaration - naturally this could only be determined on a case-by-case basis. Like you, we believe that in certain cases a single individual may have strategic insights or wisdom that allow for the shaping of strategic visions without broader consensus. Even in such circumstances, however, we would argue that it is important to develop consensus if one is to implement the strategic vision - here again it is easier to develop consensus if people are actually involved in the creation of the vision.

Once again, thank you for you insightful letter. From our perspective, the purpose of this exchange has been primarily to move leadership theory and practice beyond a historical reliance on the traditional top-down model to one that recognizes and encourages multi-directional influence processes in ways beneficial to organizational effectiveness and member self-efficacy - one that takes full advantage of the knowledge, skills, and abilities of all workers, whatever their organizational level.

Sincerely,

Craig Pearce

Jay Conger 


\section{Letter 4}

Craig Pearce

Associate Professor

Peter F. Drucker and Masatoshi Ito Graduate School of Management

Claremont Graduate University

1021 N. Dartmouth Avenue

Claremont, CA 91711

Jay Conger

Henry R. Kravis Research Chair in Leadership Studies

Claremont McKenna College

850 Columbia Ave.

Claremont, CA 91711

Dear Craig and Jay:

Just some final remarks about our discussion. First, you point out (correctly) that I had inadvertently left out three words when quoting your definition of shared leadership as: "lateral influence among peers rather than simply relying on vertical, downward influence by an appointed leader" (Cox et al., 2003, p. 48). However, these words change nothing; the key words are rather than. If we rely on lateral influence rather than simply relying on other types (such as downward influence), then it means we are doing the former in preference to the latter. The above definition does not encompass all directions of influence as does your other definition (Pearce \& Conger, 2003b, p. 1). It appears you agree with the latter definition rather than the former.

Later you note that shared leadership is a "primitive term." I see nothing wrong with the Pearce and Conger definition. Maybe what you meant is that one needs to clarify the concept itself (which is wider than the definition; Locke, 2003b), viz. share what, when and with whom? I think we both agree that such clarification would be useful.

You believe that the "crux of the issue" is to integrate the view that leadership is individual with the view that it is social. I disagree. Leadership is a concept of relationship; it assumes the existence of some people who follow one or more others. Leadership is about influence, so it is social by its very nature. There can be no leadership if there is just one person.

You caution against the "heavy" use of formal power. Now here we need clarification. What does heavy mean as opposed to medium and light? For example, does heavy mean: the CEO makes every decision (never delegating)? Or does it mean: the CEO is heavy-handed, threatening and bullying people? Or does it mean: totally specifying all means (plans) and ends (goals)? I certainly would not favor any of these, as I think I made clear in my previous note.

In reality, however, the use of CEO's position power may be more nuanced. Consider Jack Welch. He got the idea of Six Sigma at GE partly from people inside the organization but mainly from outside (Larry Bossidy). Then he mandated that all divisions (except finance) implement it, and he made it part of the performance appraisal system. He required that division heads meet regularly so they could to share their ideas with each other. He gave his division heads enormous responsibility, but he also assigned minimum goals and also stretch goals (which did not have to be met but which he hoped would inspire creative thinking). He also discussed division heads' strategic plans with them and sometimes vetoed certain plans or asked for revisions. Complaints from subordinates led him to conceive, with input from others, the Work Out program to facilitate communication between superior and subordinate. The program was then mandated. Welch was a very good listener but made firm decisions. Was Welch heavy, medium or light? I do not know, but he was surely extraordinarily successful.

Leadership is an art, so a good CEO knows when he (or she) needs full or partial consensus and when a firm, final decision has to be made. I do not think you can make specific rules about consensus; I view it as a contextual issue. Perhaps holding the right context for any given decision is one of the skills that make great business leaders great.

Sincerely,

Ed Locke 


\section{References}

Avolio et al., 2003 • B. J. Avolio, N. Sivasubramaniam, W. D. Murry, D. Jung and J. W. Garger, Assessing shared leadership: Development and preliminary validation of a team multifactor leadership questionnaire; in C. L. Pearce and J. A. Conger, editors, Shared Leadership: Reframing the Hows and Whys of Leadership, Sage, Thousand Oaks, CA (2003), pp. 141-172.

Conger and Kanungo, 1998 - J. Conger and R. N. Kanungo, Charismatic Leadership in Organizations, Sage Publishers, Thousand Oaks, CA (1998).

Conger and Pearce, 2003 - J. A. Conger and C. L. Pearce, A Landscape of opportunities: Future research on shared leadership, C. L. Pearce and J. A. Conger, editors, Shared Leadership: Reframing the Hows and Whys of Leadership, Sage, Thousand Oaks, CA (2003), pp. 285-303.

Cox et al., 2003 - J. F. Cox, C. L. Pearce, and M. L. Perry, Toward a model of shared leadership and distributed influence in the innovation process: How shared leadership can enhance new product development team dynamics and effectiveness; in C. L. Pearce and J. A. Conger, editors, Shared Leadership: Reframing the Hows and Whys of Leadership, Sage, Thousand Oaks, CA (2003), pp. 48-76.

Dunphy, 2000 - D. Dunphy, Embracing paradox: Top-down versus participative management of organizational change; in: M. Beer and N. Nohria, editors, Breaking the code of change, Harvard Business School Press, Boston (2000), pp. 123-136.

Ensley and Pearce, 2001 - M. D. Ensley and C. L. Pearce, Shared cognition as a process and an outcome in top management teams: implications for new venture performance. Journal of Organizational Behavior, 22 (2001), pp. 145-160.

Hooker and Csikszentmihalyi, 2003 - C. Hooker and M. Csikszentmihalyi, Flow, creativity, and shared leadership: rethinking the motivation and structuring of knowledge work; in C. L. Pearce and J. A. Conger, editors, Shared Leadership: Reframing the Hows and Whys of Leadership, Sage, Thousand Oaks, CA (2003), pp. 217-234.

Huy, 2001 • Q. N. Huy, In praise of middle managers. Harvard Business Review, (2001), pp. 73-79.

Kerr and Jermier, 1978 - S. Kerr and J. M. Jermier, Substitutes for leadership: their meaning and measurement. Organizational Behavior and Human Performance, 22 (1978), pp. 375-403.

Kotter and Cohen, 2002 - K. P. Kotter and D. S. Cohen, The Heart of Change: Real-Life Stories of How People Change Their Organizations, Harvard Business School Press, Cambridge, MA (2002).

Locke, 2000 - E. A. Locke, The Prime Movers: Traits of the Great Wealth Creators, AMACOM, New York (2000).

Locke, 2003a - E. A. Locke, Leadership: Starting at the top, C. L. Pearce and J. A. Conger, editors, Shared Leadership: Reframing the Hows and Whys of Leadership, Sage, Thousand Oaks, CA (2003), pp. 271-284.

Locke, 2003b - E. A. Locke, Good definitions: The epistemological foundation of scientific progress; in J. Greenberg, editor, Organizational Behavior: The State of the Science, Erlbaum, Mahwah, NJ (2003).

Locke and Latham, 1990 • E. A. Locke and G. P. Latham, A Theory of Goal Setting and Task Performance, Prentice Hall, Englewood Cliffs, NJ (1990).

Love, 1986 J. Love, McDonalds: Behind the Arches, Bantam Books, New York (1986).

McCauley et al., 1998 • C. D. McCauley, R. S. Moxley, and E. Van Velsor, The Center for Creative Leadership Handbook of Leadership Development, Jossey-Bass, San Francisco (1998).

Nadler, 1998 • D. Nadler, Champions of Change, Jossey-Bass, San Francisco (1998).

Pearce, 1997 - C. L. Pearce, The Determinants of Change Management Team Effectiveness: A Longitudinal Investigation. PhD dissertation, University of Maryland, College Park (1997).

Pearce and Conger, 2003a - C. L. Pearce and J. A. Conger, Shared Leadership: Reframing the Hows and Whys of Leadership, Sage Publications, Thousand Oaks, CA (2003).

Pearce and Conger, 2003b • C. L. Pearce and J. A. Conger, All those years ago: The historical underpinnings of shared leadership; in C. L. Pearce and J.A. Conger, editors, Shared Leadership: Reframing the Hows and Whys of Leadership, Sage, Thousand Oaks, CA (2003), pp. 1-18.

Pearce and Ensley, 2004 - C. L. Pearce and M. D. Ensley, A reciprocal and longitudinal investigation of the innovation process: the central role of shared vision in product and process innovation teams (PPITs). Journal of Organizational Behavior, 25:2 (2004), pp. 259-278.

Pearce and Sims, 2002 - C. L. Pearce and H. P. Sims, Vertical versus shared leadership as predictors of the effectiveness of change management teams: an examination of aversive, directive, transactional, transformational, and empowering leader behaviors. Group Dynamics, Theory, Research, and Practice, 6:2 (2002), pp. 172-197.

Pearce et al., 2004 • C. L. Pearce, Y. Yoo and M. Alavi, Leadership, social work, and virtual teams: the relative influence of vertical vs. shared leadership in the nonprofit sector, R.E. Riggio, S. Smith-Orr, Editors , Improving Leadership in Nonprofit Organizations, Jossey-Bass, San Francisco (2004), pp. 180-203.

Pettigrew et al., 1992 - A. M. Pettigrew, E. F. Ferlie, and L. McKee, Shaping Strategic Change, Sage, London (1992). 